\title{
Current Status and Conservation of the Scarlet Macaw (Ara macao) in the Osa Conservation Area (ACOSA), Costa Rica
}

\author{
Fiona Dear ${ }^{1,2}$, Christopher Vaughan ${ }^{1,2,3,4,7}$ and Adrián Morales Polanco ${ }^{5,6}$ \\ ${ }^{1}$ Association for Parrot Protection (LAPPA), Central Pacific, Costa Rica; fiona_dear@hotmail.com \\ International Institute for Wildlife Conservation and Management, Universidad Nacional, Costa Rica \\ ${ }^{3}$ Department of Forest and Wildlife Ecology, University of Wisconsin-Madison, Madison, WI 53706; cvaughan@wisc.edu \\ ${ }^{4}$ Milwaukee Public Museum, Milwaukee, WI 53233 \\ ${ }^{5}$ Association of Entrepreneurs for Responsible Development (ASEDER), Osa Peninsula, Costa Rica; adrianmorales@costarricense.cr \\ ${ }^{6}$ La Leona Lodge, Osa Peninsula, Costa Rica \\ ${ }^{7}$ Associated Colleges of the Midwest, San Pedro, Costa Rica
}

Received 11-XII-2009 Corrected 21-II-2010 Accepted 8-III-2010

\begin{abstract}
The status and conservation of the scarlet macaw (Ara macao) in the Osa Conservation Area (ACOSA) was studied from October to December 2005. The study consisted of a 22 question interview carried out with 105 local residents, and a workshop at which 18 locals attended. Notable results included: a) the scarlet macaw population is found throughout the entire Osa Peninsula and on the mainland with a northern limit a Playa Piñuelas; b) estimates of the population size varied between $800-1200$ individuals and it was generally believed that the numbers are increasing; c) the ACOSA scarlet macaws do not roost communally; d) At least 59 plant species (seed and fruit) are fed on by the ACOSA scarlet macaws and exotic species: beach almond (Terminalia catappa), teak (Tectona grandis) and melina (Gmelina arborea) are important; e) the scarlet macaws nests between December and May in cavities of at least 28 tree species, with ceiba (Ceiba pentandra) and garlic (Caryocar costarricense) the species most utilised; f) approximately $25-50$ chicks are poached each year, with one person responsible for poaching 25 chicks; g) three scarlet macaw release programs are based in the area of Golfito and Pavones and h) the strategic plan covers research, monitoring, outreach, marketing and conservation projects for the species. This includes studies of population dynamics, habitat, nesting ecology, genetics, chick poaching and conservation programs.
\end{abstract}

\section{KEY WORDS}

Conservation, scarlet macaw, Osa, ACOSA.

\section{RESUMEN}

Se estudió el estado y conservación de la lapa roja (Ara macao) en el Área de Conservación de Osa (ACOSA) entre octubre y diciembre del 2005. El proyecto se llevó a cabo realizando una entrevista estructurada, con 22 preguntas, a 105 adultos locales y desarrollando un taller con 18 participantes de la región, que resultó en un plan estratégico. Entre los resultados mas sobresalientes, se encontró que: a) la población de lapa roja se extiende en toda la Península de Osa y hacia el norte hasta Playa Piñuelas; b) no fue posible estimar el número de individuos en la población, pero puede existir entre 800-1200 individuos y los habitantes locales consideran que esta aumentando; c) las lapas no se concentran en sitios para pernoctar; d) se alimentan de al menos 59 especies de plantas (semilla y fruta) de las cuales tres especies exóticas se consideran importantes: el almendro de playa (Terminalia catappa), la teca (Tectona grandis) y la melina (Gmelina arborea); e) anidan entre diciembre y mayo en huecos de árboles de unas 28 especies, siendo la ceiba (Ceiba pentandra) y el ajo (Caryocar costarricense) las más utilizadas; f) existe extracción de pichones (aprox. 25-50 por año) por parte de laperos, siendo una persona la principal responsable de dicha extracción ya que colecta al menos 25 pichones anualmente; g) existen tres programas de liberación de lapas rojas, los cuales se encuentran ubicados en el área de Golfito y Pavones y h) el plan estratégico formulado contempla proyectos de investigación, monitoreo, conservación, extensión y mercadeo de la especie; lo anterior incluye estudios sobre dinámica poblacional, hábitat, ecología de reproducción, genética, extracción de pichones y programas de conservación.

PALABRAS CLAVE

Conservación, lapa roja, Osa, ACOSA. 


\section{Status of Scarlet Macaws in Costa Rica}

The scarlet macaw has been listed on appendix 1 of CITES since 1985 (Abramson \& Thomsen 1995). Originally the scarlet macaw (Ara macao) was found on both the Caribbean and Pacific sides of Costa Rica, from sea level to approximately 1500 masl. Today only two viable populations exist in the country, both on the Pacific coast (Stiles \& Skutch 1989). The larger population, with 800-1200 individuals, is located in the Osa Conservation Area (ACOSA) in the southeast of the country, while the second population with 450 individuals is found in the Central Pacific Conservation Area (ACOPAC). Small groups of 10-25 macaws are also found in other parts of Costa Rica, including Palo Verde (Tempisque Conservation Area), Barro de Colorado (Tortuguero Conservation Area) and Estrella Valley (La Amistad-Caribbean Conservation Area). In addition scarlet macaws have been released in Curú Wildlife Refuge (Paquera), Golfito and Punta Banco in ACOSA (Brightsmith et al. 2005), and Coopesilencio in the Central Pacific.

\section{Study and Conservation of Scarlet Macaws in Costa Rica}

\section{Wild populations}

The ACOPAC scarlet macaws have been studied and monitored since 1990. Together with the research in Manu/ Tambopata (Peru), this is currently one of the longest macaw studies worldwide (Nycander et al. 1995, Vaughan 2002). Scarlet macaw research in ACOPAC has included the following studies: demography (Vaughan 2002, Vaughan et al. 2005a); diet (Vaughan et al. 2006, Nemeth \& Vaughan, 2004); nesting (Vaughan et al. 2003b); range (Marineros 1993, Marineros \& Vaughan 1995) and fledgling movement and behaviour (Myers \& Vaughan 2003). Additionally work has involved local communities (Vaughan 2002) including scarlet macaw tourism (Marineros 1993) and environmental education (Vaughan et al. 2003a).

Without a doubt, one of the most important studies has been monitoring the population numbers, possible because this population follows a daily migration. The scarlet macaws roost in Guacalillo Mangrove Reserve and each morning flies in four fly-routes to the south and east towards Carara National Park and the surrounding areas. Therefore most of the scarlet macaws in the population can be counted during July and August when the maximum number of scarlet macaws follow this migration (Vaughan et al. 2005a).

Counts data showed that in 1995 the population was declining (Vaughan et al. 2005a) and the principal cause was found to be poaching of nestlings for the pet trade. This information prompted intensive conservation efforts, including protection of active nests, installation of artificial nest boxes, environmental education with local communities and the formation of a local NGO to coordinate conservation of scarlet macaws and other parrots in the area (Vaughan 2002). The intensive efforts in 1996 and 1997 resulted in a population increase, demonstrated by results from the continuing population counts (Vaughan et al. 2005a).

\section{Reintroduced Populations}

Data concerning survival of the reintroduced scarlet macaws in Curú y Golfito were summarised in Brightsmith et al. (2005) and a recent study by Forbes (2005). A study of the genetics of captive scarlet macaws in Costa Rica was carried out by Nader et al. (1999)

\section{Study of Scarlet Macaws in ACOSA}

Although the ACOSA scarlet macaw population is believed to be the largest nationally, this population has been little studied. Research conducted in this area included studies of abundance and group size in the northeastern part of the Osa Peninsula (De la Ossa et al. 1998) and density estimates of 1.94 individuals/ km2 (De la Ossa, L. \& P. Riba. Sf. Biología reproductiva y monitoreo poblacional de la lapa roja (Ara macao) en el Parque Nacional Corcovado y sus zonas de amortiguamiento. 9 p. Informe no publicado)

However long-term studies of this population have not been carried out, therefore current status and ecology is unknown.

For this reason a preliminary study was carried out based on interviews conducted with local residents to research the ecology of and threats to the ACOSA scarlet macaws. The results of this study are presented below.

\section{METHODOLOGY}

\section{Study Site}

ACOSA is located in the South East corner of Costa Rica and consists of an area of $4104 \mathrm{~km} 2$. The Osa peninsula includes 10 national wildland areas (Vaughan \& Rodriguez 1997) in an area composed of primary forest and a complex system of fresh and salt water resources. After long periods of isolation, the peninsula joined with the Mesoamerican isthmus several million years ago. Its unique forests and hydrological systems are distinct from the rest 
of the dry Pacific coast, which has produced high levels of biodiversity including many endemic species.

The Osa Peninsula includes Corcovado National Park, which forms part of the Mesoamerican Pacific coast's last remaining tract of lowland humid forest. The peninsula has more than 5,000 vascular plan species, many unique to science, including the new genus Ruptiliocarpon (Lepidobotryaceae). The rainforest is composed of more than 700 tree species, the highest level of diversity in Central America. Preliminary inventories have found the following number of species: 140 mammal, 367 bird, 117 reptile and amphibian, 40 freshwater fish and at least 6000 insect. Yearly rainfall is between $3-4 \mathrm{~m}$ on the coast and $5-6 \mathrm{~m}$ at the highest points $(600 \mathrm{~m})$ (Vaughan \& Rodriguez 1997). Outside Corcovado National Park, land is mainly dedicated to African oil palm, gmelina and teak plantations, cattle pastures and rice paddies. The principal threats to ACOSA's nature include hunting, gold mining and small scale timber harvesting (Vaughan \& Rodriguez 1997).

\section{Interviews}

From October 15 to November 17 (2005), structured, open interviews (Margoluis \& Salfasky 1998) were carried out with residents of ACOSA (Appendix 1). Interviewees were selected due to their vast knowledge of wildlife and/ or because they were long-time residents of the area. Interview areas were selected in two ways. The principal towns in the Osa Peninsula were visited between October 15-20 and the information received from initial interviews allowed us to focus on the following themes: a) range limits of the population; b) high incidence of macaws; c) ecological data (diet, reproduction, and nesting) and d) high incidence of chick poaching.

To identify the population's range limits, residents near the suspected limits were asked about scarlet macaw presence until areas were found where they were not present. Long-time residents were asked dates when scarlet macaws left and/or returned to the area. To understand the most important areas for the population, interviewees were asked the greatest number of macaws seen in one day in their area or other areas they had knowledge about.

\section{Strategic Plan}

In association with MINAE and Friends of Osa, a workshop to strategically analyze the threats to the ACOSA scarlet macaw population was held on 16th November (2005) using Measures of Success: Designing, Managing and Monitoring Conservation and Development projects (Margoluis \& Salfasky 1998). This allowed threats to the population to be aired and those factors and objectives to be identified, along with activities to solve the identified threats. The results were written up to create a management and monitoring plan.

\section{RESULTS}

\section{Professional and Economic Profile of Interviewees}

Interviews were carried out with 105 residents representing more than 30 areas within ACOSA (Table 1). Because of its inaccessibility, park guards in Puerto Jimenez and Carate provided information for Corcovado National Park. Most interviewees (89\%) had lived in the area for more than 10 years. The most common professions were tourism (42\%), agriculture (25\%) and general commerce (15\%) (Fig. 1) . Also, $67 \%$ had a primary or lower level of education, $18 \%$ had received education to secondary level and $15 \%$ had reached university level.

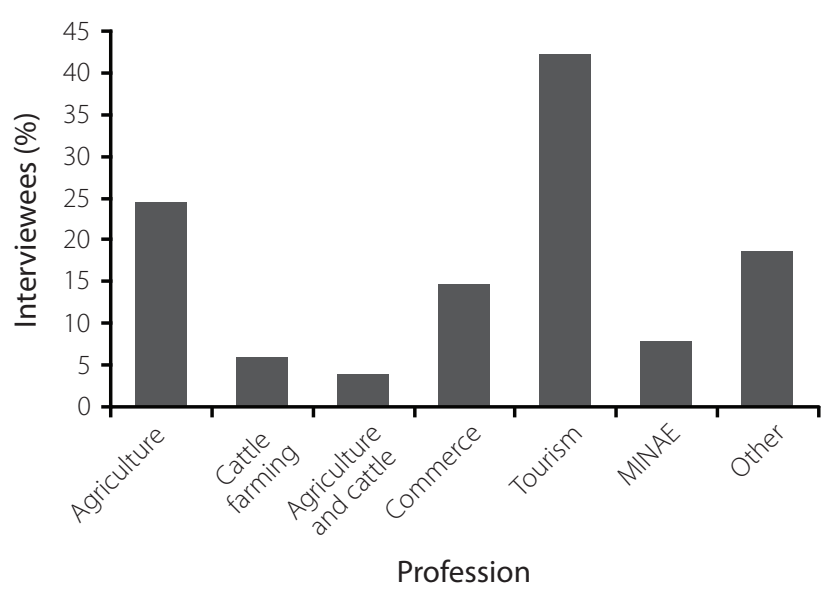

FIG. 1. Profession of interviewees $(n=105)$ in the Osa Conservation Area.

\section{Scarlet Macaw Population in ACOSA}

\section{Range limits}

The range limits of the ACOSA scarlet macaw population were found to be located outside the Osa Peninsula with the northern limit in Playa Piñuelas (Fig. 2). The 
TABLE 1

Interview sites and number of interviewees in each area

\begin{tabular}{|c|c|c|}
\hline Place & $\begin{array}{c}\text { Max. \# of } \\
\text { macaws seen }\end{array}$ & $\begin{array}{l}\text { Number of } \\
\text { interviews }\end{array}$ \\
\hline Taboga & 4 & 1 \\
\hline Santa Cecilia & 4 & 1 \\
\hline Los Mogos & 5 & 3 \\
\hline Cerro de Oro & 5 & 3 \\
\hline Ciudad Cortez & 6 & 2 \\
\hline Bahía Chal & 7 & 3 \\
\hline Guadalupe & 11 & 4 \\
\hline Coronado & 12 & 1 \\
\hline Rincón & 12 & 2 \\
\hline Gallardo & 13 & 2 \\
\hline Miramar & 15 & 1 \\
\hline La Palma & 16 & 3 \\
\hline Sierpe & 17 & 4 \\
\hline Sándalo & 18 & 2 \\
\hline Drake & 19 & 3 \\
\hline Palmar Norte & 21 & 2 \\
\hline El Tigre & 21 & 4 \\
\hline Palmar Sur & 23 & 2 \\
\hline Rio Nuevo & 25 & 1 \\
\hline Amapola & 27 & 2 \\
\hline Palo Seco & 30 & 4 \\
\hline Puerto Jimenez & 30 & 4 \\
\hline Progreso de Drake & 33 & 2 \\
\hline Cañaza & 35 & 2 \\
\hline La Leona & 35 & 1 \\
\hline Corcovado National Park & 40 & 1 \\
\hline Matapalo & 45 & 8 \\
\hline Boca Coronado & 46 & 1 \\
\hline Carate & 62 & 10 \\
\hline Rancho Quemado & 63 & 4 \\
\hline Playa Blanca & 63 & 5 \\
\hline Piro & 67 & 4 \\
\hline Rio Oro & 74 & 8 \\
\hline Guaymi Reserve & 100 & 1 \\
\hline Pejeperro & 200 & 1 \\
\hline
\end{tabular}

residents there indicated that macaws were rarely seen, while residents farther north said scarlet macaws were never seen in these parts. The southern mainland limit in ACOSA was Chacarita where residents had seen scarlet macaws passing only 1-2 times in recent years. In La Gamba, Piedras Blancas and Golfito to the south, interviewees agreed that scarlet macaws are not found in these areas, apart from reintroduced scarlet macaws (Fig. 2).

According to Golfito residents, scarlet macaws disappeared from the region between 20 and 55 years ago. However, in La Gamba one person claimed that scarlet macaws were present in the town 30 years ago, while others stated they had never been there. Scarlet macaws disappeared from the town of Sierpe in the 1960s, but residents began to see scarlet macaws in the town about 5-10 years ago. In Palmar Sur, residents claimed that macaws left the area 50 years ago and began returning about 4-10 years ago. Scarlet macaws disappeared from Palmar Norte 20 years ago and returned in the last 5-10 years. However several interviewees in Palmar Norte stated that although scarlet macaws were rare in the area until recent years, they never left the area entirely. Residents of Ciudad Cortes maintained that scarlet macaws had always been present in the area (Table 2).

\section{Status of the population}

Of 105 interviews, 89 (85\%) believed that scarlet macaws are now more abundant than 5 years ago, 12 interviewees $(11 \%)$ considered the population had remained stable and $4(4 \%)$ thought there are now fewer scarlet macaws. Fifty three (53) of the interviewees (50\%) did not know why the population had increased. However the others said that the population increased $(n=52)$ for the following reasons: 28 (54\%) stated that it was due to protection, $11(21 \%)$ because of an increase in awareness in the region, $4(8 \%)$ due to tourism, $4(8 \%)$ because of an increase in exotic trees and 5 (10\%) for other reasons.

\section{Concentrations of scarlet macaws in ACOSA}

Values for the maximum number of scarlet macaws seen in one day were averaged for each interview site (Fig. 2). Two reports were discounted as they were deviated too much from the average (200 scarlet macaws in Pejeperro and 100 scarlet macaws in the Guaymi reserve). Rio Oro was the site with the highest number of macaws (74 macaws, $\mathrm{n}=8$ interviewees, Table 1$)$. Other areas of high scarlet macaw incidence included: Piro $(67 n=4)$, Playa Blanca $(63 n=5)$, Rancho Quemado (63 $n=4)$ and Carate $(62 n=10)$ (Fig. 2). However the scarlet macaw was found throughout the Osa Peninsula. 


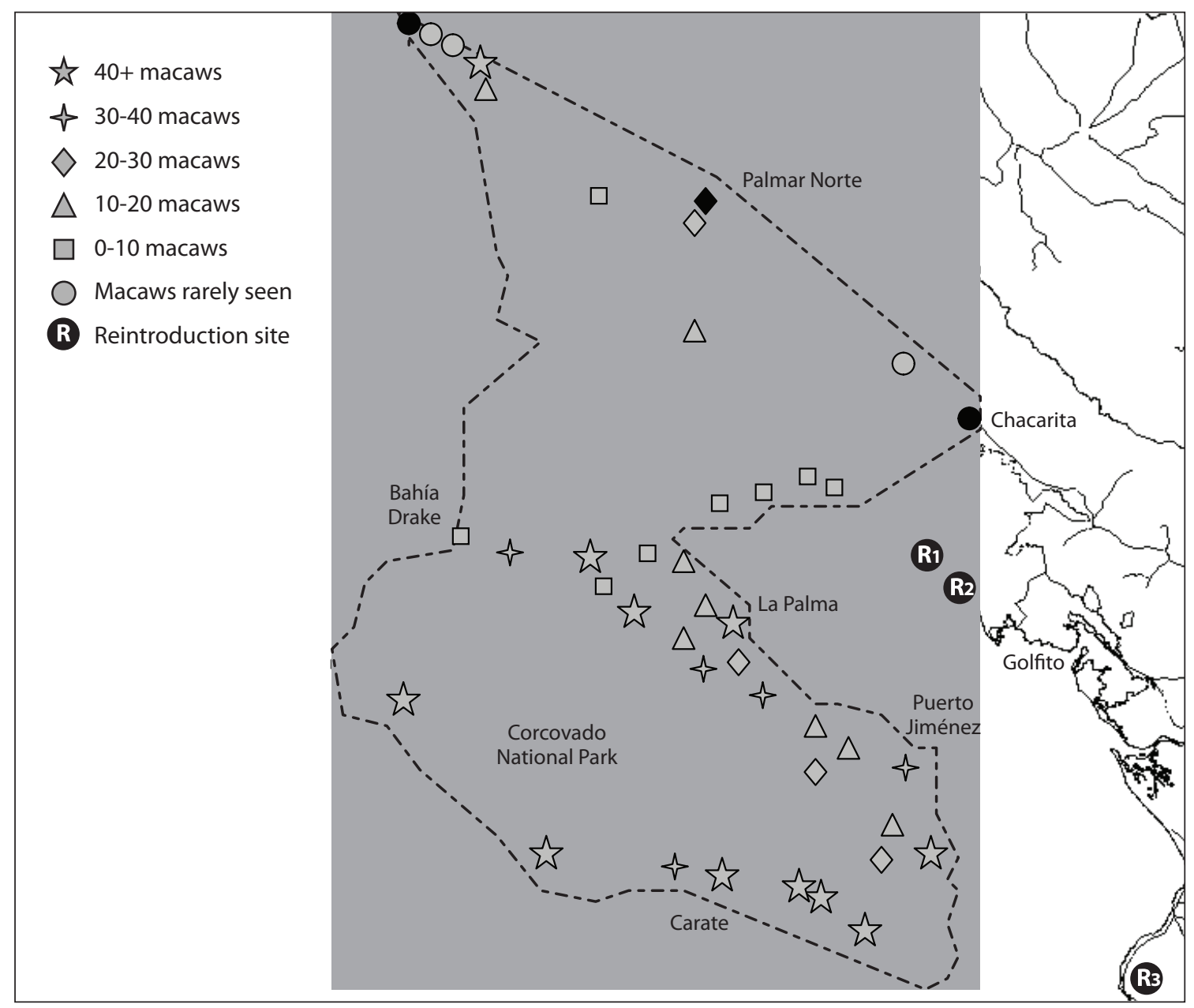

FIG. 2. Estimated range (grey shading) and macaw frequency (average number of individuals seen in one day in each area) in ACOSA.

TABLE 2

Dates of the scarlet macaw population's local extinction and re-colonisation of areas outside the Osa Peninsula

\begin{tabular}{lcc}
\hline \multicolumn{1}{c}{ Town } & Years macaws disappeared & Years macaws returned \\
\hline Los Mogos & - & $2-6$ \\
Sierpe & $35-45$ & $5-10$ \\
Palmar Norte & 20/ macaws never disappeared & $5-10$ \\
Palmar Sur & 50/ macaws never disappeared & $4-10$ \\
C Cortez & Macaws never disappeared & \\
Coronado & 40 & 5 \\
La Gamba & 30/ macaws never in area & $\mathrm{N}$ \\
Golfito & $20-55$ & $\mathrm{~N}$
\end{tabular}




\section{Roosting and Potential Counting Sites}

A roosting site comparable to that of the ACOPAC population was not discovered during the study. According to many interviewees, scarlet macaws sleep in forest in the centre of the peninsula. Of the roosting sites suggested by more than one person, the following sites were mentioned: A ceiba tree in La Palma $(n=4)$; behind the coastal ridge in Carate $(n=4)$; a ceiba tree in Palmar Norte $(\mathrm{n}=2)$ and a ridge beside the Palmar Norte - Boca Coronado highway $(n=2)$ (Fig. 3).

Many suggestions for counting sites were received. Carate was the site most often mentioned ( $n=19)$, with the Look Out Inn hotel was mentioned on three occasions. Also suggested

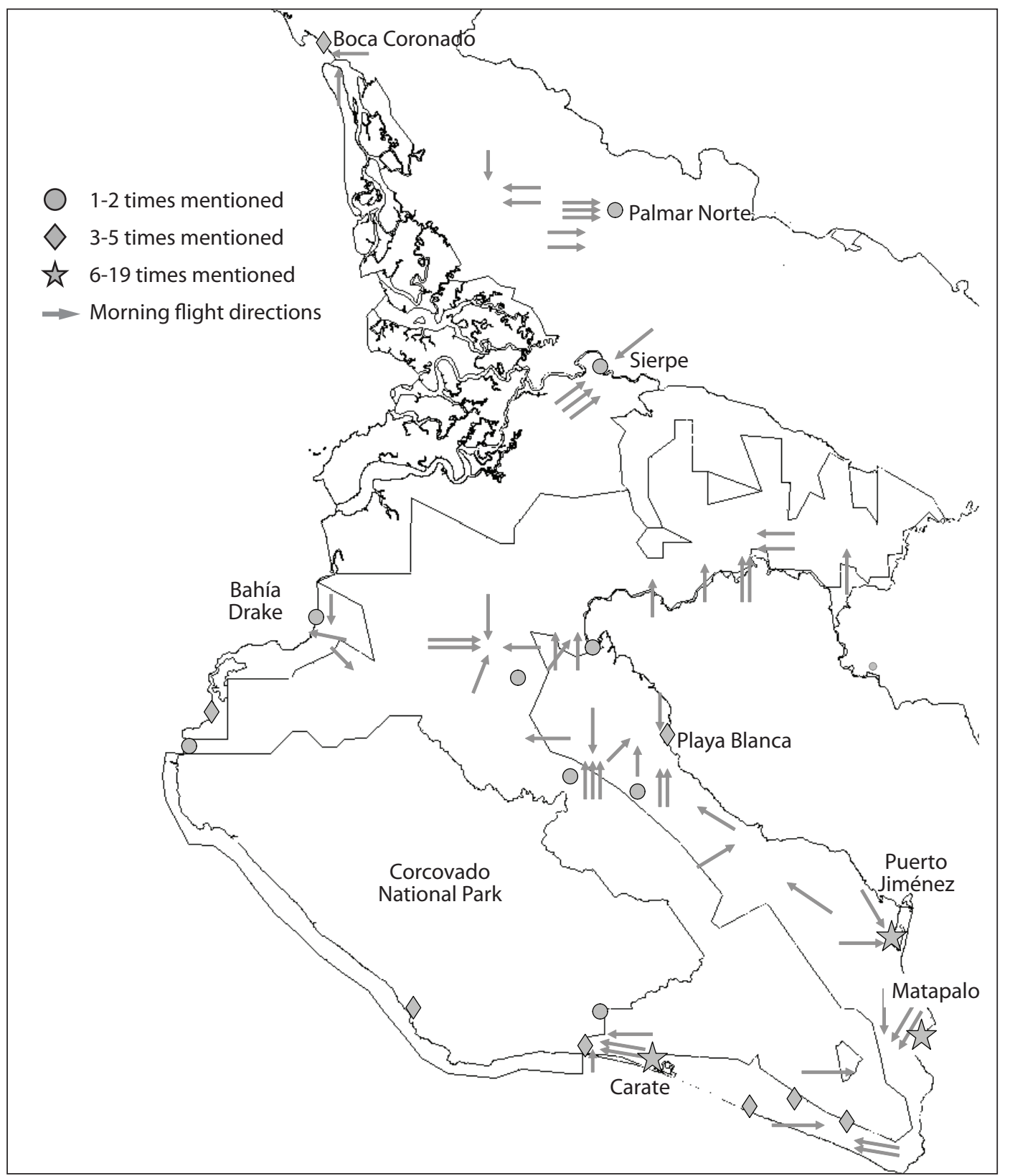

FIG. 3. Potential scarlet macaw counting sites and morning flight directions in ACOSA. 
in the close to this area were Piro $(n=4)$, Rio Oro $(n=4)$, Laguna Pejeperro $(n=5)$ and Playa Madrigal $(n=4)$. Other areas mentioned included: Matapalo $(n=11)$; Puerto Jimenez $(n=9)$; Playa Blanca $(n=5)$ and Boca Coronado ( $n=4)$ (Fig. 3).

\section{Scarlet Macaw Diet in ACOSA}

Fifty nine plant species fed on by scarlet macaws were mentioned by interviewees (Table 3). Of these species, only 17 are utilised as food by the ACOPAC macaw population (Vaughan et al, 2006). Interviewees indicated the months in which they had seen scarlet macaws eating each species, however the answers varied greatly from published data for this area (Quesada et al. 1997). The most commonly mentioned exotic species were: beach almond (Terminalia catappa, 92\%), teak (Tectona grandis, $41 \%$ ) and melina (Gmelina arborea, 16\%). The seed was the plant part mentioned eaten by scarlet macaws for all species, with the exception of the flower of Balsa (Ochroma pyramidale) and the fruit of Palma Real (Scheelea rostrata).

\section{Scarlet Macaw Nesting}

According to the interview results $(n=69)$ the scarlet macaw breeding season in ACOSA begins in December and ends in May (Fig. 4), this period is similar to the ACOPAC nesting season (Vaughan et al. 2003b). As the macaws weren't nesting during the study months
(October-November), nests were not visited. However 38 interviewees stated they were willing to show macaw researchers a total of 120 known nests, although the true number of nests is probably much lower because of repetition between interviewees. A total of 28 host tree species were mentioned. The most commonly mentioned were Ceiba (Ceiba pentandra, mentioned by $36 \%$ of interviewees), Ajo (Caryocar costarricense, 34\%), Gallinazo (Schizolobium parahybum, 14\%), Espavel (Anacardium excelsum, 10\%) and Zapatero (Hyeronima alchorneoides, 10\%).

\section{Poaching of Nestlings}

Approximately half of the interviewees (48\%) believe that macaws are still poached and the others stated the activity does not currently exist (52\%). Additionally $43 \%$ of the interviewees mentioned that there is now less poaching activity than before and nobody said the activity had increased. It was estimated that chick poaching became less common in the last 1 to 20 years ( $x=8$ years). Only $14(13 \%)$ interviewees estimated the number of chicks poached each year. The estimations varied from 3 to 50 chicks removed from their nests each year ( $x=19$ ), however park guards believed that at least 25 chicks are poached each year by one person.

Scarlet macaw chicks are bought by tourists, resident foreigners, Costa Ricans from out of ACOSA and Panamanians. However it appears that nestlings are both sold to

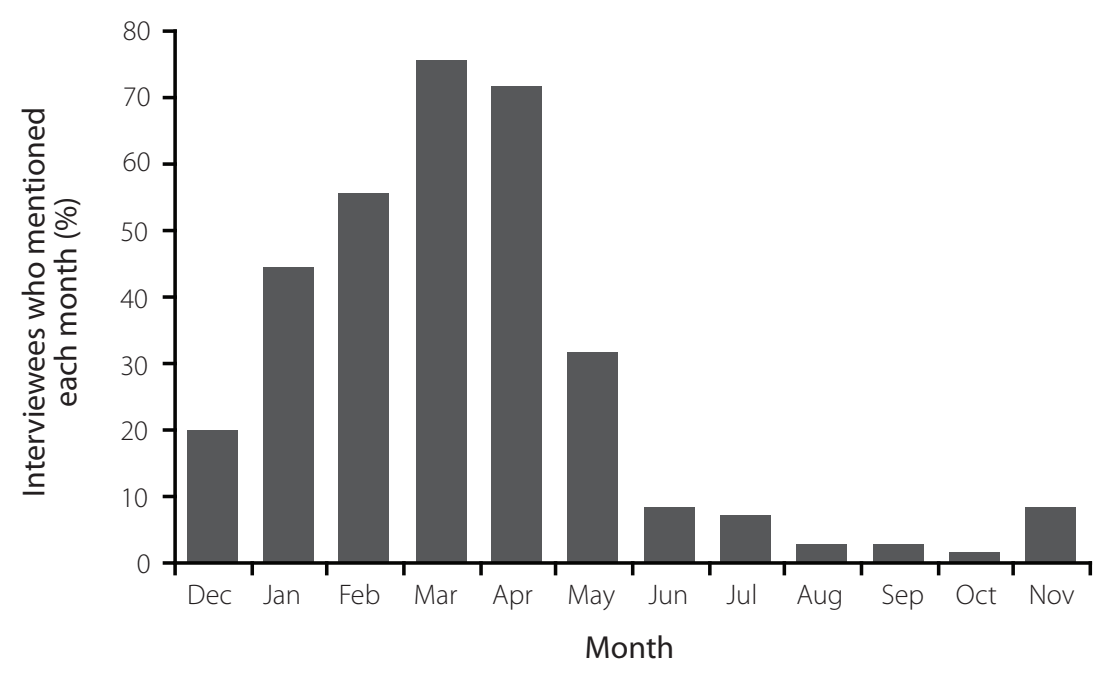

FIG. 4. Answers $(n=69)$ regarding scarlet macaw nesting months in ACOSA. 
TABLE 3

Plant species utilised as food by scarlet macaws in ACOSA

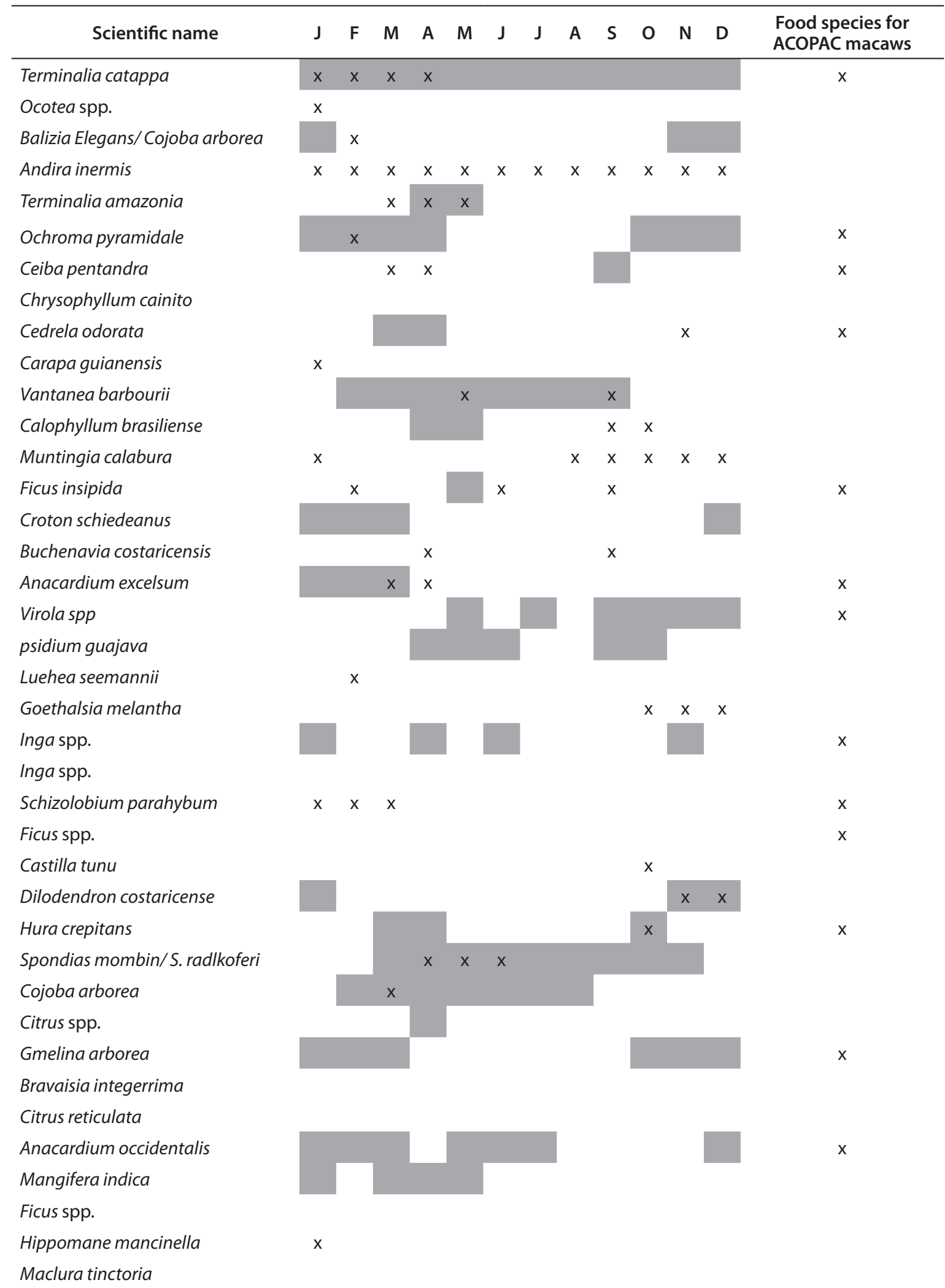


TABLE 3 (Continued...)

Plant species utilised as food by scarlet macaws in ACOSA

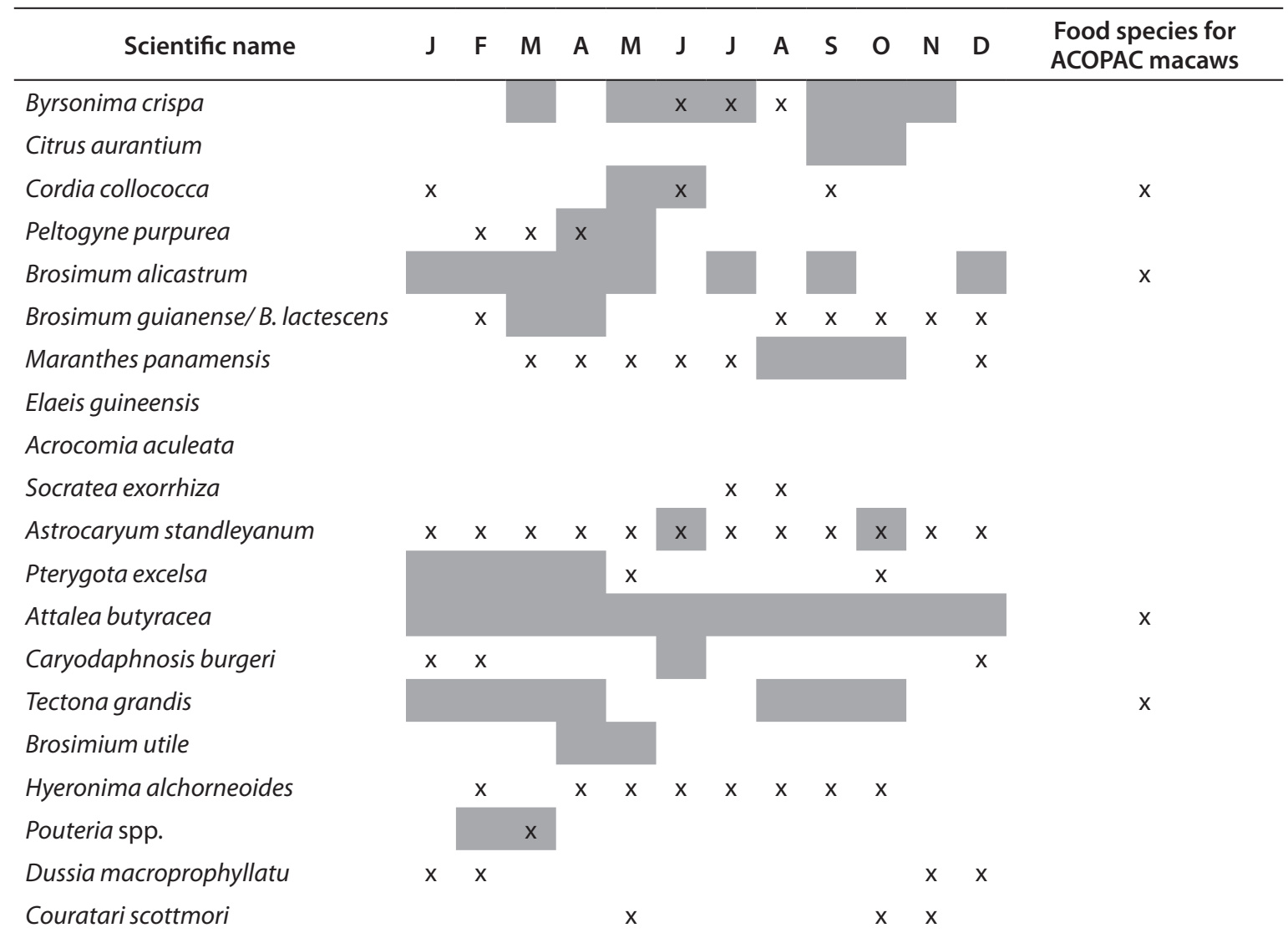

Grey shading marks the months macaws feed of each species according to interviewees, $\mathrm{x}$ indicates fruiting periods according to Quesada et al. 1997

intermediaries and directly to buyers. The selling price of each chick varied between $\$ 10,000$ (US\$20) and $\$ 750,000$ (US\$1,500), with an average of $\$ 120,000$ (US\$240). The areas of highest poaching activity were Rio Oro $(n=10)$, Rio Nuevo (7), Puerto Jimenez (7) and Cañaza (6) (Fig. 5).

\section{Scarlet Macaw Reintroduction Programs}

Three scarlet macaw release programs, coordinated by three organisations are located in the areas of Golfito and Pavones: Osa Wildlife Sanctuary (R1); Zoo Ave (R2) and Amigos de las Aves (R3) (Fig. 2, Table 4).

Santuario Silvestre de Osa, R1 - is located at Caña Blan$\mathrm{ca}$, on the coast close to Piedras Blancas. This sanctuary receives macaws confiscated from poachers in the area, which are released in the area surrounding the sanctuary.
The first release was in 1997 with one bird. Regular releases began in 2001 and to date 9 macaws have been released and all are alive.

Zoo Ave, R2 - is located in Alajuela with a breeding and rescue centre and the release site is located in Playa San Josecito in Golfito. Confiscated macaws are received from all parts of the country. Normally only the offspring of the confiscated macaws are released, however five confiscated macaws (ages unknown) have been released in Golfito. The first macaws were released in 1999 and $63 \%$ of the released macaws were observed alive in 2002 (Brightsmith et al. 2005)

Amigos de las Aves, R3 - is also based in Alajuela with a breeding and rescue centre. The confiscated macaws here are received from all parts of the country but never released. Offspring are released in flocks at ages of between 


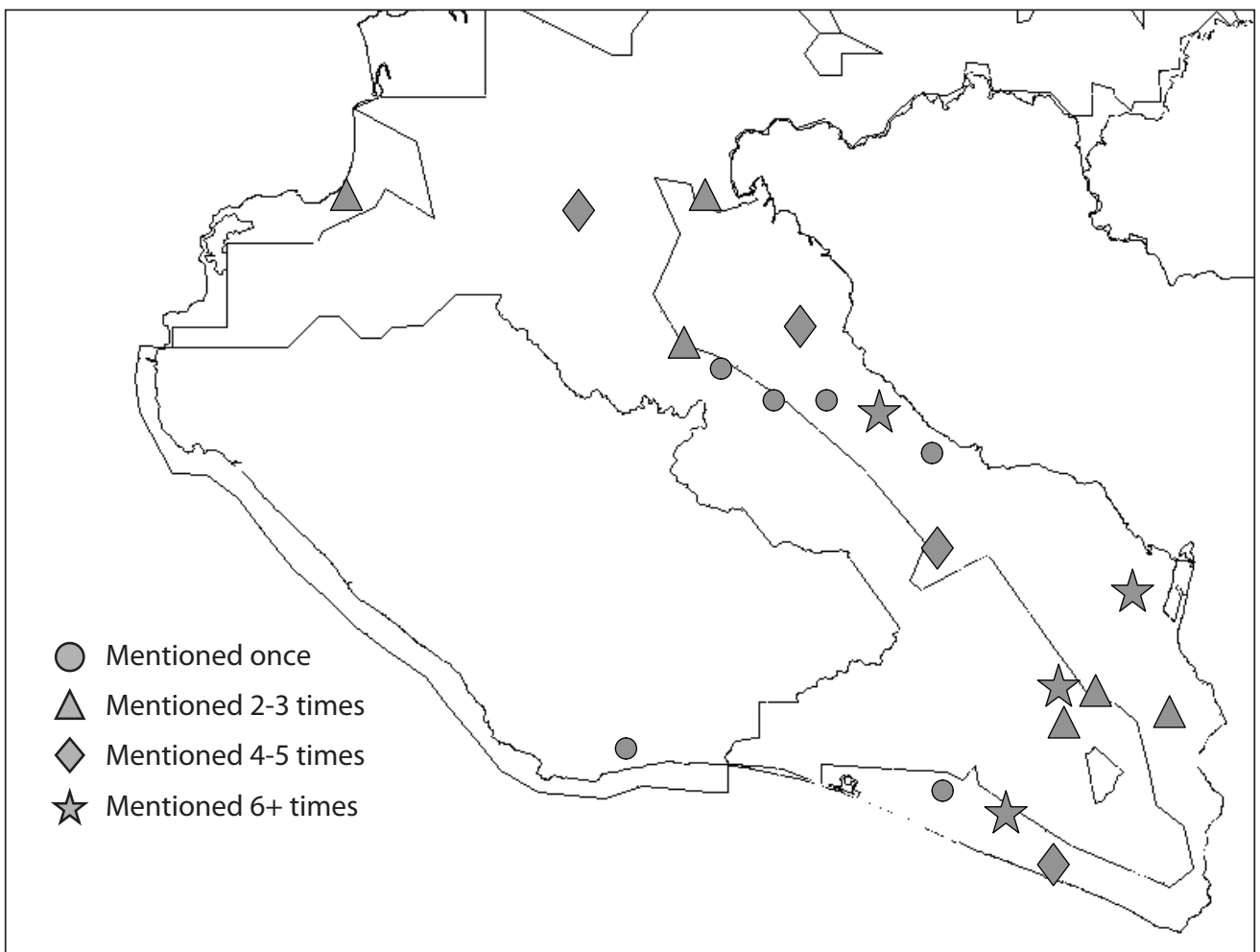

FIG. 5. Areas of ACOSA identified to have a high level of scarlet macaw poaching activity.

TABLE 4

Details of scarlet macaw release programs in ACOSA

\begin{tabular}{lccccc}
\hline Release program & Code in Fig. 2 & $\begin{array}{c}\text { \# macaws } \\
\text { released }\end{array}$ & $\begin{array}{c}\text { \# macaws } \\
\text { surviving }\end{array}$ & $\begin{array}{c}\text { Date of first } \\
\text { release }\end{array}$ & Origin of macaws \\
\hline Amigos de las Aves & R3 & 34 & 34 & Sep 2002 & Costa Rica, unknown \\
Zoo Ave & R2 & 34 & $24^{*}$ & 1999 & Costa Rica, unknown \\
Caña Blanca & R1 & 9 & 9 & $1997(1)$ & Puerto Jimenez (2), Rio \\
& & & & 2001 & Tigre (2), Carate (1) \\
& & & & Rancho Quemado (2) \\
& & & & Cañaza (1) Sándalo (1)
\end{tabular}

* As of December 2002. Information from Brightsmith et al. 2005 
2 and 4 years in Punta Banco. The first macaws were released in 2002; to date a total of 34 macaws have been released, all of which have survived. With each release the range of the flock has grown to reach a current range of 84 $\mathrm{km}^{2}$ (Forbes 2005).

\section{Strategic Plan}

The workshop to plan conservation and research of the ACOSA scarlet macaws was held on the November 16th 2005. Eighteen participants attended from communities within the Osa Peninsular (Puerto Jiménez; La Palma; El Tigre; Piro and Carate) and the mainland (Piedras Blancas; Caña Blanca y Punta Banco). Invitees from Drake and Piro were unable to arrive due to heavy rains. The issue of the scarlet macaw and its conservation in ACOSA was discussed and six objectives were planned for the project:

- Design and implement a research and monitoring program

- Reduce chick poaching

- Involve the local communities in the project

- Develop environmental education programs focused on the scarlet macaw

- Conserve and restore scarlet macaw habitat

- Ensure the long term economic sustainability of the project

The objectives and corresponding activities were written into a conceptual model and management plan for the scarlet macaw in ACOSA (Vaughan et al. 2005b).

\section{DISCUSSION}

\section{Professional and Economic Profile of Interviewees}

The high percentage of interviewees working in tourism is significant. The sampling was not random and biased toward the person who works in tourism and those with knowledge of natural history. Results for the schooling levels show that most have no or elementary level education.

\section{Scarlet Macaw Population in ACOSA}

\section{History of scarlet macaws in ACOSA}

Before the arrival of banana companies in Southern Pacific Costa Rica in the 1940's, scarlet macaws were abundant in the ACOSA area. According to inhabitants, at this time the destruction of wildlife was fast and scarlet macaws were affected by both habitat loss and direct persecution. Several interviewees told of residents killing scarlet macaws for entertainment as well as for food. For this reason, scarlet macaws were rarely seen outside the peninsula until 10 years ago.

\section{Current population size and possible reasons for its in- crease}

Estimates range between 800-1200 scarlet macaws. In addition to the range increase over the last decade, the vast majority of interviewees (89\%) believed that today there are more macaws than 5 years ago. The local inhabitants attribute the increase of macaws in ACOSA to:

- Protection of macaws by MINAE;

- People see that more money can be obtained from tourism than from macaw chick poaching;

- Environmental education programs, particularly the campaign: "Worth more free than in captivity";

- The availability of more forest for food and nests;

- The introduction of exotic flora which macaws utilize for feeding.

It is clear that no single factor has been responsible for the population increase. Many people feel the law won't work if people are not in agreement. Therefore the change in attitudes due to factors $b$ and $c$ has been vital. An important point mentioned frequently was that locals now appreciate the scarlet macaws and won't harm them. In previous years children would frequently throw stones at scarlet macaws for fun, however this is no longer accepted. This understanding has been easier with scarlet macaws due to their charisma, they are frequently sighted and scarlet macaws are not a pest species for crops. According to one interviewee, one scarlet macaw nest with easy access in Guadalupe (La Palma) was left un-poached in 2005 although the nest received no direct protection. This story reflects a positive attitude of local people. In other areas, an accessible nest without direct protection would be poached (FD pers. obs., ACOPAC). Tourism has also impacted areas such as Matapalo, where tourist ventures have replaced farms. Consequently farm workers who were previously involved in chick poaching have now left the areas or changed their attitudes.

\section{Concentrations of scarlet macaws in ACOSA}

Although the scarlet macaw population is found throughout many parts of ACOSA, the largest concentrations of scarlet macaws are found within the Osa Peninsula, particularly the southern part. The distribution of 
macaws shown in Fig. 2 is more a reflection of the location of interviewees. Corcovado National Park and the Sierpe mangroves are said to be stronghold for scarlet macaws, but these sites were interviewed. We must visit these areas to confirm the presence of macaws and complete the map.

Areas with highest density of scarlet macaws are found between Carate and Piro and other beach areas where the macaws groups feed on beach almond. The only exception is Rancho Quemado, where macaws grouped to feed on melina. Both species (beach almond and melina) are exotic. The macaws' use of these species is discussed in the section 'use of exotic species'

\section{Roosting and Potential Counting Sites}

\section{Detected sites}

In ACOPAC's Guacalillo mangrove reserve, the population's roosting site, the ideal site to count scarlet macaws is when they leave in the mornings to feed, or return to roost in the afternoons. In the last decade, counts have been carried out only in July and August when fledglings follow the migration with their parents. Thus, we can calculate an average population size and young-adult ratio (recruitment).

However, it seems that in ACOSA, scarlet macaws congregate in smaller numbers (up to 50 individuals) in various sites. No roosting or frequent grouping site for large numbers of scarlet macaws was found. Rain during the study months (October and November) precluded searching for fly routes due to the quantity of rain. Also during these months, scarlet macaws search for and defend nests in preparation for the breeding season.

Aware that the macaw population could roost in isolated areas, which are not known by locals, interviewees were asked in what direction the macaws fly each morning and afternoon. Several potential morning flight patterns include: a) macaws follow the coast of Matapalo southwards, then fly northwest from the cape; b) macaws arrive in Rincón and La Palma from the south; c) Macaws arrive in the towns between Rincon and Chacarita from the beaches at the north of the Golfo Dulce and d) macaws may roost to the east of Palmar Norte (Fig. 3). Patterns $a$ and $b$ could indicate presence of a site in the southeast of the peninsula where scarlet macaws leave in the mornings. One site which appears promising is Boca Coronado (Fig. 3). Four people recommended this site and one interviewee stated he had counted 46 macaws passing at 6:30am one morning.

\section{Options for future population counts}

A lack of fixed counting sites precludes a complete population count. However partial counts from various sites could be carried out yearly simultaneously in July and August when all young have fledged. These could then be compared between years to monitor demographic patterns shown by the population. Comparing the young-adult ratios during July and August from these sites could be an important index of the population's reproductive success and the impact of management each year (Vaughan et al 2005a).

\section{Scarlet Macaw Diet in ACOSA}

\section{Native species}

Interviewees had observed macaws feeding on 59 plant species. To confirm this food species list, we must observe macaws feeding directly and collect samples for identification.

\section{Use of exotic species}

Exotic plant species are important in ACOSA scarlet macaw diets. Almost every interviewee mentioned beach almond and frequently teak and melina. These species are probably well known and generally located close to human dwellings. However various interviewees suggested that scarlet macaws utilise these species when native food sources unavailable. This must be confirmed (Table 3 ) and could bring problems to scarlet macaws when the plantations are cut.

An estimated 12,272 ha of melina exist in ACOSA. However, approximately half are located outside the ACOSA scarlet macaw range (Kaddelle et al. 2003). According to the Kaddelle et al. (2003), teak plantations do not exist within scarlet macaw range, however plantations of this species have been seen both on the Osa Peninsula and the north part of the range (FD pers. obs.) and this species is available to scarlet macaws until plantations are harvested. In Rancho Quemado, up to 85 scarlet macaws were observed feeding on melina until plantations were recently harvested. Today scarlet macaws are rarely seen in the area. This case illustrates the risk of scarlet macaws becoming accustomed to feeding on exotic timber species.

The planting and harvesting of plantations should be carefully planned to provide food for scarlet macaws when food shortages exist for other species. Although the plantations' harvesting plans were investigated, information collected was conflicting and time limits prevented further enquiries. Contacting plantation managers will 
provide information on long-term management plans for this food source. Valuable native timber species have also been felled, eliminating nests and food sources for scarlet macaw during certain stages of the year.

\section{Scarlet Macaw Nesting}

Nests must be visited during the breeding season to verify its state (active/ inactive). The most common nest species (Ceiba and Gallinazo) are also the most important nesting species in ACOPAC for scarlet macaw (Vaughan et al. 2003b). Ajo (Caryocar costarricense) is extracted for timber and is also a very important nesting species for the ACOSA scarlet macaws, but it isn't found in ACOPAC. The bigger individuals of this species might have nesting cavities and are target for timber. A study of the availability of this species and a plan to protect large individuals should be priorities for the project.

\section{Nestling Poaching}

\section{Poachers}

The information in this section is based on reports from several knowledgeable individuals. Although results suggest incidence of chick poaching has decreased, the activity still exists and threatens the population. Approximately 50 chicks might be stolen from their nests yearly. Most poachers in ACOSA are poor locals who remove a small number of chicks yearly to increase their income. Only one 'full time' poacher was mentioned by several interviewees, who extracts approximately 25 chicks per year. Although this man is known by MINAE, he hasn't been stopped. This person alone is responsible for removing over half of the chicks taken yearly and this must be stopped.

\section{Transport of poached chicks}

Several interviewees stated that stolen macaw chicks are transported in barrels, which enter the Peninsula carrying sugar water (mile) for cattle and leave containing scarlet macaw chicks. In recent years, a MINAE strategy has been to stop and search cars leaving the Peninsula. Several interviewees believed this has lowered scarlet macaw poaching activity. Others suggested chicks are removed from the peninsula in boats directly to Golfito.

\section{Ultimate destination of poached chicks}

Information about buyers of poached scarlet macaws was limited, partly because the researcher was a stranger to the locals. Answers varied, however a general consensus was that poached scarlet macaws do not remain in the area. One reliable informant commented that there are now fewer scarlet macaw traders. In addition many interviewees knew about animals confiscated by MINAE, which helped lower the demand locally.

\section{Patterns of chick poaching}

Chick poaching reduction was attributed as one of the main factors in the population's increase in recent years (see "Current population size and possible reasons for its increase"). Most of the areas cited to have a high incidence of poaching are regions with little tourism; se perhaps towns receiving benefits from nature tourism, the locals are more aware of the harm caused by illegal wildlife exploitation and refrain from carrying out these activities.

However, several practices related to natural resources have changed in the Peninsula. Various interviewees mentioned that previously trees would be felled to access chicks. Elimination of this potential nest sites might threaten the population more than chick poaching. Fortunately this practice is no longer carried out in this area. Additionally shooting a scarlet macaw's wing to capture adult scarlet macaws seems to have disappeared.

\section{Other Threats}

\section{Hunting}

Hunting was one of the main reasons for the disappearance of the scarlet macaw population in Golfito and surrounding areas. Today although isolated cases exist of people killing macaws, is no longer a major threat to the population.

\section{Capture of adults}

The capture of adult macaws for the pet trade was a threat mentioned exclusively in Playa Blanca. However several interviewees there commented that in 2004 an adult macaw was trapped while feeding on beach almond. The poachers used fishing line to ensnare the individual's foot, and the macaw was caught. As the macaws in ACOSA are so 'tame', an increase in this practice could become a serious threat to the population. This was, however an isolated case and it is hoped that it remains as such.

\section{Reintroduction of Scarlet Macaws}

The destiny of scarlet macaws released in the Golfito area (R1 y R2) is unknown, however macaws may have travelled to Los Mogos. In addition, although wild macaws have not been observed in Piedras Blancas, wild scarlet macaws in the Los Mogos area might be utilizing the coast 
to the south of the town. Therefore wild and reintroduced populations could be mixing.

Reintroduction of psittacines has been a subject of scientific debate (Snyder et al. 2000). If wild and released macaws are in contact, there are risks of dangerous diseases passed to the wild population with no resistance. Released scarlet macaws accustomed to humans could invoke behavioural changes in native scarlet macaws. For instance, scarlet macaws allowing humans to approach closely could facilitate the capture of adults.

The existence of reintroduction programs could be either an advantage or disadvantage for the natural population. Releases could aid in recolonisation of the macaw population's original range. However, macaws from the wild population have not returned to these sites suggests that the habitat in this area lacks something which is necessary for the macaws' survival. This should be a priority for future research.

\section{Recommendations}

\section{Studies}

\section{Population dynamics}

- Monitor the population size and any annual fluctuations; and

- Monitor population sizes and fluctuations of other psittacine species in the area.

\section{Habitat}

- Identify with direct observations plant species utilised by the scarlet macaws for food and study the phenology of these species;

- Identify scarlet macaw nests, nesting ecology, nesting success and the availability of important species such as Caryocar costarricense;

- Research the number and size of Tectona grandis y Gmelina arborea plantations and their harvesting plans;

- Study the habitat within and outside the macaw range on the mainland to understand factors limiting the growth of the population's range.

\section{Genetics}

- Study the population's genetics, including that of released populations.

\section{Poaching}

- Maintain a continuous register of poaching denouncement and estimate the level of chick poaching annually;
- Study the socioeconomic factors leading to chick poaching in ACOSA

Conservation (These recommendations are based on the management plan objectives)

- Stop chick poaching;

- Involve local communities in the project, both in planning and carrying out project activities;

- Develop environmental education programs focused on the scarlet macaw;

- Conserve and restore scarlet macaw habitat;

- Ensure the long term economic sustainability of the project

Based on interviews and observations, the ACOSA scarlet macaw population is currently stable with the distribution thought to be increasing. However a large gap exist in scientific data regarding ecology (population dynamics, habitat, nesting, genetics, diet) and threats including nestling poaching. In addition, no conservation or outreach programs exists for the species other that that coordinated by MINAE. Fortunately hunting of adults does not exist in this area which could have a grave impact on the population. The presence of a group of people willing to collaborate with the project and a general positive attitude towards scarlet macaw (and other species) conservation in ACOSA is positive for scarlet macaw conservation. Finally impact of the three reintroduction programs to the south of Golfito needs to be evaluated.

\section{ACKNOWLEDGEMENTS}

The following institutes are thanked for their assistance: LAPPA; The Parrot Society-UK; Department of Wildlife Ecology (University of Wisconsin); International Institute for Wildlife Management and Conservation; Osa Conservation Area (MINAE); and La Leona Lodge. The Evergreen Foundation financed the study. Maria Hermes and Marleny Rosales edited the manuscript and offered useful comments. Steven Bell, Mike Boston, Jonas Spahn, Eliécer Arce and Annia Cordero Mendez offered important logistic help.

\section{REFERENCES}

Abramson, J. \& J. B. Thomsen. 1995. Identification and profiles, p. 1-37 In: J. Abramson, B. L. Speer, \& J. B. Thomsen (Eds.) The Large Macaws: Their Care, Breeding and Conservation. Raintree Publications, Fort Bragg, California, USA. 
Brightsmith, D., J. Hilburn, A. del Campo, J. Boyd, M. Frisius, R. Frisius, D. Janik \& F. Guillen. 2005. The use of hand-raised psittacines for reintroduction: a case study of scarlet macaws (Ara macao) in Peru and Costa Rica. Biological Conservation. 121: 465-472.

De la Ossa, L., Riba, P. \& J. Villareal. 1998. Abundancia y tamaño de grupo de la lapa roja (Ara macao) en el noreste de la Península de Osa, Costa Rica. Memorias del II congreso y III asamblea general de la Sociedad Mesoamericana para la Biología y Conservación, 6-10 de july, Managua, Nicaragua.

Forbes, D. 2005. Reintroducción exitosa de la lapa roja (Ara macao) en los bosques secos y húmedos de Costa Rica: Su supervivencia, movimientos y dieta. Asociación Amigos de las Aves. Memorias del I Simposio de Psitácidos, 21-25 de November, La Ceiba, Honduras.

Kaddelle, M., M. Castro, H. Acezedo, L. Gonzales \& H, Monge. 2003. Ecosistemas del Área de Conservación Osa (ACOSA). Instituto Nacional de Biodiversidad, Santo Domingo de Heredia, Costa Rica.

Margoluis, R. \& N. Salafsky. 1998. Medidas de Éxito: Diseño, Manejo y Monitoreo de Proyectos en Conservación y Desarrollo. Island, Washington, D.C., USA.

Marineros, L. 1993. La lapa roja (Psittacidae: Ara macao): Ecología, turismo y pautas para su manejo en la Reserva Biológica Carara, Costa Rica. Tesis de Maestría, Universidad Nacional, Costa Rica.

Marineros, L. \& C. Vaughan. 1995. Scarlet Macaws of Carara, p. 445-467, In: J. Abramson, B. Speer \& J. Thomsen (Eds) The large macaws: their care, breeding and conservation. Raintree Publications, Fort Bragg, California, USA.

Myers, M. \& C. Vaughan. 2003. Movement and behavior of scarlet macaws (Ara macao) during the post-fledging dependence period: implications for in situ versus ex situ management. Biological Conservation 118: 411-420.

Nader, W., D. Werner \& M. Wink. 1999. Genetic diversity of scarlet macaws Ara macao in reintroduction studies for threatened populations in Costa Rica. Biological Conservation 87: 269-272.

Nemeth, N. \& C. Vaughan. 2004. Feeding observations on Scarlet Macaw Ara macao in Costa Rica. Cotinga 21: 71-72.
Nycander, E., D. Blanco, K. Holle, A. Del Campo, C. Munn, J. Moscoso \& D. Ricalde. 1995. Nesting success and techniques for increasing reproduction in wild macaws in southwestern Peru, 423-444 p., In: J. Abramson, B. Speer \& J. Thomsen (Eds). The large macaws: their care, breeding and conservation. Raintree Publications, Fort Bragg, California, EEUU.

Quesada Q., Q. Jiménez, N. Zamora, R. Aguilar \& J. González. 1997. Arboles de Osa. Instituto Nacional de Biodiversidad, Santo Domingo de Heredia, Costa Rica.

Snyder, N, P. McGowan, J. Gilardi \& A. Gramal. 2000. Parrots: Status survey and conservation action plan 200-2004. IUCN, Gland, Switzerland and Cambridge UK.

Stiles, F. G. \& A. F. Skutch. 1989. Birds of Costa Rica. Cornell University. New York, USA.

Vaughan, C. \& C. Rodriguez. 1997. Managing beyond the borders: the Costa Rican System of Conservation Areas (SINAC). Pages 441-451. In G. Meffe \& R. Carroll (eds.). Principles of Conservation Biology. 2nd Edition. Sinauer Press, Sunderland, Massachusetts, USA.

Vaughan, C. 2002. Conservation strategies for a Costa Rican scarlet macaw population. Ph.D dissertation, University of Wisconsin, Madison, Wisconsin, USA.

Vaughan, C., J. Gack, H. Solórzano \& R. Ray. 2003a. The effect of environmental education on school children, their parents and community members: A study of intergenerational and intercommunity learning. Journal of Environmental Education 34: 12-21

Vaughan, C., N. Nemeth \& L. Marineros. 2003b. Ecology and management of natural and artificial Scarlet Macaw (Ara macao) nest cavities in Costa Rica. Ornitología Neotropical 14: 381-396.

Vaughan, C., N. Nemeth, J. Cary \& S. Temple. 2005a. Conservation strategies for a Scarlet Macaw (Ara macao) population in Costa Rica. Birdlife International 15:119-130.

Vaughan, C., F. Dear \& A. Morales. 2005b. Marco conceptual de una estrategia para proteger la lapa roja (Ara macao) en el Área de Conservación Osa (ACOSA), Costa Rica. MINAE/ ACOSA/Friends of Osa.

Vaughan, C., N. Nemeth \& L. Marineros. 2006. Scarlet Macaw (Ara macao) diet in Central Pacific Costa Rica. Revista de Biología Tropical 54:919-926. 